A RTIGOS

\title{
A RELIGIÃO DOS BANTOS: NOVAS LEITURAS SOBRE O CALUNDU NO BRASIL COLONIAL
}

The Bantus religion: new interpretations

of calundu in colonial Brazil

ROBERT DAIBERT

http://dx.doi.org/10.1590/S0103-21862015000100002

Robert Daibert é mestre em História pela Unicamp, doutor em História pela UFRJ e professor do Programa de Pós-Graduação em Ciência da Religião da Universidade Federal de Juiz de Fora (robertdaibert@uol.com.br).

Artigo recebido em 31 de dezembro de 2014 e aprovado para publicação em 7 de abril de 2015. 


\title{
ResUmo
}

0 artigo tem como proposta apresentar uma síntese das características centrais da tradição religiosa africana banto. 0 objetivo é demonstrar que o conhecimento desses elementos, enquanto repertório simbólico disponível aos praticantes do calundu, pode trazer novas reflexões a respeito desta experiência religiosa no período colonial. Pretende-se, assim, incentivar futuras investigações que não privilegiem o sincretismo como elemento de diluição das heranças africanas, mas levem em conta os modos de sobrevivência, reatualização e transformação das tradições religiosas banto no Brasil.

PalaVras-CHAVE: tradição religiosa banto, calundu, religiosidade afro-brasileira.

\begin{abstract}
This article aims to present a synthesis of the main characteristics of the Bantu African religious tradition. The idea is to demonstrate that the knowledge about the symbolic repertory of the Calundu practitioners may stimulate new reflections about this religious experience of colonial times. We so intend to stimulate future investigations that will not consider syncretism as an element of dilution of the African heritage, but will pay attention to the ways Bantu religious traditions have survived and have been transformed in Brazil.
\end{abstract}

KeY wORDS: Bantu religious tradition, Calundu, African-Brazilian religiosity.

\section{RÉSUMÉ}

L'article se propose à présenter une synthèse des caractéristiques centrales de la tradition religieuse africaine bantoue. Notre objectif est de montrer que la connaissance du répertoire symbolique disponible aux pratiquants du calundu peut susciter des nouvelles réflexions sur cette expérience religieuse du Brésil colonial. Nous cherchons ainsi à encourager des recherches qui ne regardent pas le syncrétisme comme un élément de dilution des héritages africains, mais qui tiennent compte des modes de survie, de réactualisation et de transformation des traditions religieuses bantoues au Brésil.

MoTs-CLÉS: tradition religieuse bantoue, calundu, religiosité afro-brésilienne. 
a manhã do dia 12 de agosto de 1743, o Tribunal do Santo Ofício de Lisboa submeteu Luzia Pinta a uma sessão de tortura. ${ }^{1}$ Após ter seu vestido arrancado, ela foi deitada em um potro, espécie de estrado de madeira com saliências pontiagudas, sobre o qual seu corpo foi amarrado com correias de couro. Como era de costume, nesse tipo de tortura essas cordas eram puxadas com intensidade de modo a comprimir o torturado contra as pontas de seu leito (Dines, 1992: 1007).

Luzia era natural de Luanda, Angola, onde viveu antes de ser levada para o Brasil pelo tráfico negreiro no início do século XVIII. Os inquisidores tentavam desvendar os significados dos serviços espirituais que ela prestava à população de Minas Gerais em um ritual identificado como calundu. 0 recurso à tortura era usado para descobrir possíveis evidências de um pacto demoníaco em suas práticas religiosas. Ao final, ela conseguiu escapar da morte, mas não foi considerada inocente. Na ausência de provas explícitas, seu pacto foi presumido. Sentenciada pela "abjuração de leve suspeita de ter abandonado a fé católica" , Luzia foi para sempre proibida de retornar a Sabará, e foi ainda condenada a quatro anos de degredo no Algarve.

De alguma forma, as perguntas sobre o significado do calundu de Luzia Pinta e de outros escravizados que transplantaram crenças, rituais e significados religiosos africanos para o Brasil atravessaram os séculos seguintes. Ao menos desde a década de 1980, esse ritual tem sido interpretado de forma variada e continua suscitando discordâncias e novas interpretações por parte dos historiadores (Souza, 1986: 267-268, 355, e 2002: 293-317; Mott, 1994: 80-81).

James Sweet (2003: 143-151) considerou o calundu colonial uma espécie de aglutinação de variados ritos de cura praticados na África Central que tinham em comum o fenômeno da possessão por espíritos. A palavra calundu, segundo o autor, seria uma variante do vocábulo quilundu, termo usado para designar qualquer tipo de espírito responsável por causar doença ou aflição passível de ser curada por meio da intervenção de um sacerdote. Nesse sentido, segundo o autor, a abrangência desse significado amplamente difundido entre a comunidade escrava teria facilitado, no território colonial, a designação do calundu como uma religião centro-africana transplantada para o Brasil e responsável pelo tratamento de tormentos e angústias. 
Sweet (2003: 7), entretanto, rejeitou a ideia de um sincretismo entre as religiões africanas e o catolicismo. Sem negar, obviamente, o contato entre elas, o autor defendeu a permanência de profundas diferenças entre os dois universos. A seu ver, se por um lado os africanos praticavam o catolicismo de modo superficial, por outro, as religiões africanas teriam permanecido intocadas e independentes em seu sistema de pensamento. Nesse sentido, para ele, 0 calundu deve ser encarado como uma religião tipicamente centro-africana recriada no Brasil. 0 peso dado pelo autor às recriações e transplantes intocados das religiões africanas no Novo Mundo o impediu de perceber uma interessante dinâmica dialógica.

Em sua leitura do calundu de Luzia Pinta, Alexandre Marcussi (2006: 117) afirmou que a angolana possuía uma espécie de dupla interpretabilidade que lhe conferia uma dupla legitimidade. Ao invés de escolher entre duas cosmologias, classificando-as como verdadeira e profunda ou falsa e superficial, Luzia elaborou um repertório simbólico acionado de acordo com as circunstâncias.

Nesse sentido, o autor vê no calundu de Luzia Pinta uma estratégia de mediação simbólica por meio de uma interpretação própria das duas tradições em diálogo. Nesse processo ela teria criado "um texto cultural particular, nem bem português, e nem exatamente angolano, mas um texto próprio da zona de mediação intercultural na qual viveu" (Marcussi, 2006: 122). Essas proposições de Alexandre Marcussi são bastante pertinentes para pensarmos a inserção do calundu de Luzia no mundo atlântico. Sua experiência na diáspora africana certamente potencializou sua habilidade em jogar com um repertório simbólico banto disponível ao seu alcance desde a infância. Mas que repertório era esse?

Até o presente momento, a historiografia não esclareceu de modo satisfatório quais eram as características e os preceitos gerais dessa tradição africana banto disponíveis a Luzia Pinta e a outros praticantes do calundu. Quais eram os elementos fundamentais sobre os quais se estruturava a religião dos bantos e que compunham um grande repertório simbólico com o qual ela podia jogar, selecionando lembranças e esquecimentos na construção de seu texto próprio enquanto sujeito da diáspora africana no Brasil?

\section{COSMOLOGIA E TRADIÇÕES CENTRO-AFRICANAS: A RELIGIÃO DOS BANTOS}

\footnotetext{
$\mathrm{O}$ s bantos são um conjunto de povos que habitavam a África Central nas regiões que hoje compreendem Angola, Congo, Gabão e Cabinda. Apesar das diferenças étnicas, esses povos compartilhavam o mesmo tronco linguístico: eram falantes das línguas bantos. Essa base comum permitiu que muitos traços culturais e significados religiosos fundamentais
} 
fossem compartilhados entre os diferentes grupos dessa grande região, vista hoje como um espaço geográfico menos heterogêneo do que se imaginava (Craemer; Vansina; Fox, 1976: 458-475). Embora os vários grupos étnicos dessa parte do continente apresentassem uma grande diversidade cultural, é possível detectar em todos eles a presença de uma única cosmologia centro-africana, aqui chamada de religião dos bantos, espécie de substrato comum e base a partir da qual se fundamentava a diversidade de suas experiências religiosas. Os autores citados a seguir têm como objetivo apresentar uma síntese dos principais elementos da tradição religiosa banto. Suas fontes de pesquisa dividem-se basicamente entre observações antropológicas de experiências religiosas nas sociedades bantos e relatos de missionários católicos que atuaram nessas mesmas localidades.

Segundo Altuna (1985: 58-61), a religião dos bantos era estruturada a partir da crença em uma pirâmide vital, dividida entre o mundo invisível e o mundo visível. Em uma ordem hierárquica de importância, no primeiro grupo encontravam-se a divindade suprema, os arquipatriarcas, os espíritos da natureza, os ancestrais e os antepassados. No segundo grupo estavam situados os reis, os chefes de reino, tribo, clã ou família, os especialistas da magia, os anciãos, a comunidade, o ser humano, os animais, os vegetais, os minerais, os fenômenos naturais e os astros.

Segundo a tradição religiosa banto, a vida é sustentada por um Ser Supremo que reina sobre o universo e sobre os homens de modo distante, porém benéfico. Todos os povos que compartilhavam a cosmovisão banto acreditavam em um deus único, supremo e criador, chamado de Kalunga, Zambi, Lessa ou Mvidie, entre outros nomes, de acordo com o grupo étnico específico e com os atributos que se pretendia destacar nessa divindade, como a totalidade da vida, a superação de tudo em todos, a força e a inteligência. Segundo essa crença, após a criação do mundo, o Ser Supremo se distanciou dele, entregando sua administração aos ancestrais fundadores de linhagens, seus filhos divinizados. Por ser um deus distante, ele quase não recebia culto ou adoração, nem era representado por imagens. Apesar disso, conservava a dinâmica e a ordem do cosmo, mantendo o mundo unido (Munanga, 1996: 62; Éboli, 2010: 29, Malandrino, 2010: 80). Como um Deus maior e criador do universo, atuava sobre o mundo inteiro; sendo às vezes concebido como o ancestral original ou ancestral do primeiro ser humano (Thornton, 2008: 86).

Abaixo da divindade suprema estavam os arquipatriarcas, fundadores dos primeiros clãs humanos e dos grupos primitivos que receberam a vida diretamente de Deus e foram encarregados de perpetuá-la. ${ }^{2}$ Abaixo dessa categoria situavam-se os espíritos tutelares ou gênios da natureza, que habitavam os lagos, os rios, pedras, ventos, florestas ou objetos materiais. Esses seres, embora não possuíssem forma humana, exerciam grande influência sobre 
os homens, notadamente sobre as atividades da caça, pesca e agricultura. Além disso, criados pelo Ser Supremo, atuavam sobre os fenômenos da natureza uma vez que estavam ligados ao ar, à terra, às águas e à vegetação (Giroto, 1999: 150).

Os povos bantos, em sua diversidade, atribuíam importância variada a esses espíritos da natureza. Em alguns casos eles eram vistos como intermediários entre a divindade suprema e os homens, sendo por isso alvo de invocações, oferendas e sacrifícios. Em outros, esses espíritos não eram concebidos como entidades autônomas, e sim como expressões ou reflexos das ações do Deus criador. Havia ainda, por fim, a compreensão de que esses seres confundiam-se com os próprios ancestrais (Vansina, 1965b: 26; Giroto, 1999: 150-151).

Em todo caso, seja abaixo desses gênios da natureza ou ao lado deles na pirâmide vital, encontravam-se os ancestrais, espíritos fundadores de linhagens, venerados por terem deixado uma herança espiritual favorável à evolução de sua comunidade. Eram eles os responsáveis por garantir a solidariedade e a estabilidade de um grupo no tempo e sua coesão no espaço (Lopes, 2008: 149-152). Esses "grandes mortos" receberam do Deus criador a energia vital e atuavam como elo entre os homens e essa divindade suprema. Eram figuras quase míticas, e muitas vezes não se tinha conhecimento detalhado sobre suas histórias (Malandrino, 2010: 83). Em alguns casos, no entanto, eram considerados fundadores de comunidades por terem firmado as primeiras alianças com os espíritos da natureza.

Logo abaixo dos ancestrais, na hierarquia espiritual, merecia grande destaque a figura dos antepassados. Mais próximos dos seres humanos, eles eram em geral parentes próximos e, como defuntos mais recentes, eram personalizados. Para que o espírito de uma pessoa falecida se tornasse um antepassado era preciso considerar a forma como ele morreu e a conduta que teve em vida. Era preciso ter deixado as marcas de uma boa conduta moral, ter vivido até a velhice, não ter se suicidado, e ter deixado grande descendência. Além disso, o antepassado deveria se manifestar em algum vivo por meio da possessão, enviando mensagens aos seus familiares com os quais passava a desenvolver uma relação de muita proximidade. Todos esses sinais apontavam para o perfil do antepassado que, assim como os ancestrais, passava a ser cultuado e assumia a função de intermediário entre o Ser Supremo e determinada comunidade dos vivos. Embora falecidos, os antepassados continuavam membros ativos do grupo familiar e da comunidade a que pertenceram durante sua vida. Eles se tornavam os guardiões e os protetores de seus parentes vivos. Em contrapartida, o grupo familiar precisava alimentá- los e cultuá-los. Caso contrário, eles podiam acabar esquecidos da memória dos vivos com 0 passar do tempo (Malandrino, 2010: 70, 78, 83-88).

Alguns antepassados, em decorrência de seus feitos notáveis e da perpetuação de seu culto no tempo, conseguiam ascender à condição de ancestrais, assumindo um caráter mais 
divinizado (Alcantara, 2008: 37). Em alguns grupos étnicos de matriz banto, os ancestrais chegavam a atingir tamanho grau de sacralização que podiam até mesmo ser considerados divindades secundárias ou, conforme o caso, de primeira ordem (Lopes, 2008: 150). Já os antepassados que não atendiam a esses requisitos preservavam-se mais humanizados, destacando-se no empenho em aumentar a força vital de suas famílias e comunidades (Alcantara, 2008: 37). Havia situações também em que determinados antepassados caíam no esquecimento na medida em que deixavam de ser cultuados na sucessão de gerações.

Na segunda parte da pirâmide, mundo visível, o homem possuía a maior força. Nessa categoria, o grau hierárquico dos seres humanos variava conforme sua função na comunidade. Em ordem de importância encontravam-se: os reis, os chefes do clã, de famílias, os especialistas da magia e os anciãos. Todos eles eram figuras revestidas de significados sagrados, inclusive os que ocupavam cargos políticos. Para os objetivos específicos deste texto, merecem destaque os especialistas da magia e os anciãos. Estes últimos eram vistos como depositários da plenitude da sabedoria, guardiões da tradição e espécies de "bibliotecas vivas" (Altuna, 1985: 171). Geralmente atuavam nas sociedades de matriz banto como sustentáculos da cultura, transmitindo aos mais jovens histórias e crenças. Cabia aos anciãos a responsabilidade de tomar decisões que mantinham a unidade do grupo. Por estarem naturalmente mais próximos da morte, acreditava-se também que eles estavam mais próximos do mundo dos mortos e, consequentemente dos antepassados e ancestrais (Silva, 2009: 73-75).

Antes de compreendermos o papel dos especialistas da magia e caracterizarmos as forças impessoais, é necessário entender melhor a noção de força vital. 0 sentido geral da cosmovisão compartilhada pelos povos bantos era que o mundo invisível governava o mundo visível e que este último atuava e se comunicava com o primeiro por meio de interações estabelecidas por rituais. Entre os bantos, tais práticas religiosas eram baseadas no complexo cultural ventura/desventura, espécie de paradigma que entendia o universo como algo constituído originalmente pela harmonia, bem-estar, saúde, segurança, poder, status, riqueza e fecundidade (ventura) (Craemer; Vansina; Fox, 1976: 461). 0 estado de equilíbrio sintetizado pela ideia de força ou boa vida, como expressão da ausência do mal, era dividido em três grupos de valores. 0 primeiro deles estava ligado à fecundidade que incluía gerar filhos, ser bem-sucedido nas caçadas e colheitas. 0 segundo incluía as noções de segurança e proteção garantidas pela invulnerabilidade e impunidade. Já o terceiro grupo estava associado ao desejo de melhoria na posição social por meio da prosperidade nos bens materiais (Craemer; Vansina; Fox, 1976: 467-469).

Havia também a crença nas forças malévolas que, por meio de pensamentos e sentimentos malignos, podiam direta ou indiretamente causar danos como doença, morte, em- 
pobrecimento, esterilidade, corrupção, desavenças, escravidão e toda sorte de experiências negativas. Assim, a ordem natural, estado de equilíbrio e felicidade, podia ser quebrada muitas vezes pela ação de espíritos ou de pessoas que, por meio da feitiçaria, conseguiam impor o infortúnio e a doença (desventura). Todos os acontecimentos positivos e que traziam felicidade aos seres humanos eram explicados como aumento da força vital (ventura), e tudo que trazia sofrimento, dor ou infelicidade era explicado como diminuição da força vital (desventura).

A noção de força vital é um valor supremo na tradição religiosa banto, espécie de chave de compreensão de seus fundamentos e concepção de mundo. É ela que move os homens e o universo. Nessa visão, o mundo é concebido como energia e não como matéria, de modo que a noção de força toma o lugar e se confunde com a noção de ser. Todo ser é por definição força, e não uma entidade estática, e por isso a pessoa humana tem caráter dinâmico. Em outras palavras, o ser não existe em um primeiro momento para depois ser revestido de força, ou para em algum momento possuir força. 0 ser é força em sua constituição. Mas a energia vital não se limita aos vivos. Sua fonte é um deus supremo e único que distribuiu essa força aos ancestrais e aos antepassados no mundo espiritual e, em seguida, no mundo dos vivos, respectivamente aos reis, chefes de aldeias, de linhagens, anciãos, pais, filhos, ao mundo animal, aos vegetais e aos minerais. Esses mundos encontram-se inteiramente interligados, de modo que, como numa teia de aranha, não se pode vibrar um único fio sem gerar movimento em todos os outros. A força vital pode aumentar ou diminuir por meio da lei da interação das forças, de modo que um ser pode fortalecer ou enfraquecer outro ser. As próprias instituições sociais e políticas estão ancoradas nessa noção (Malandrino, 2010: 56; Munanga, 1996: 62-63).

Movidas por essa noção de força vital, as comunidades centro-africanas preservavam o valor da solidariedade, entendida como vivência compartilhada dessa energia. Nessa teia, a pessoa estava diretamente conectada aos membros daquela localidade, aos reis, chefes e sacerdotes, aos seus descendentes, ascendentes, antepassados, ancestrais e à própria divindade suprema. Todos se influenciavam mutuamente, seja para aumentar a vida, seja para debilitá-la. Como parte de uma cadeia hierárquica, um ser humano (em sua própria força vital) estava subordinado a outras forças vitais maiores ou mais desenvolvidas do que a sua própria força. Acima do ser humano estavam seus pais, os feiticeiros, seus antepassados, seus ancestrais. Todos eles tinham o poder de influenciar sua vida, fortalecendo ou enfraquecendo sua força vital (Malandrino, 2010: 56; Munanga, 1996: 62-63).

Assim, os povos bantos só entendiam a vida no sentido comunitário. Viver não era simplesmente existir, mas sim interagir com a comunidade, estar em movimento nessa grande cadeia de relações e conexões expressas na pirâmide vital, movimentando-se pela comunidade, com a comunidade e para a comunidade. Isso não significava de modo algum viver em 
igualdade, já que, como vimos, havia gradações que distinguiam a força vital dependendo da proximidade com os antepassados e ancestrais, na hierarquia das forças dispostas na pirâmide. Quanto mais perto dessas entidades, maior o nível de força vital, quanto mais afastado, maior a debilidade (Altuna, 1985: 47, 56, 434; Tempels, 1961).

Por compreender sua posição na pirâmide vital, os vivos deviam obedecer aos seus mortos, prestando-Ihes oferendas e sacrifícios. Caso contrário, um antepassado podia possuir um descendente como forma de reclamar maior estreitamento de laços entre ambos e combater possíveis negligências nas obrigações rituais. Após o conserto, obtido por meio de ritos adequados, o descendente muitas vezes assumia a condição de mediador entre o mundo dos vivos e o mundo dos mortos, tornando-se oficiante do culto desse espírito, mobilizando seu poder para outros atendimentos em rituais (MacGaffey, 1986: 107-113). Essa liderança era exercida por sacerdotes que agiam como adivinhos e curandeiros. Detentores de palavras de encantamento, esses especialistas da magia eram capazes de captar e dirigir a energia vital por meio de rituais (Malandrino, 2010: 101). Em outros termos, essas lideranças eram reconhecidas por sua capacidade de, por meio de rituais específicos, manipular ou interferir na cadeia de interações da força vital que perpassavam o mundo visível e o mundo invisível.

Mortos e vivos formavam assim uma só comunidade, em uma relação marcada por obrigações recíprocas. Se os vivos falhassem em seus compromissos, podiam ser castigados com doenças ou outras formas de esgotamento de suas forças vitais. Esse enfraquecimento era por vezes também atribuído à ação de espíritos malévolos ou de feiticeiros. Para solucionar o problema, era necessário recorrer a um líder religioso capaz de adivinhar os motivos pelos quais determinados espíritos atacavam um certo corpo. Em seguida, eram prescritos alguns remédios à base de raízes e ervas ou rituais destinados a apaziguar os algozes (Sweet, 2007: 128-129).

Por fim, cabe aqui um comentário sobre as forças impessoais, material imprescindível para o trabalho dos especialistas da magia. Dispostas no mundo visível, segunda parte da pirâmide, logo abaixo das forças pessoais encontravam-se as forças impessoais. Essas forças estavam distribuídas da seguinte forma em ordem de importância: animais, plantas e minerais. Todas elas proporcionavam energia e vitalidade ao homem. Enquanto os animais emprestavam suas características, os vegetais e minerais, conforme sua utilização em rituais, guardavam propriedades ocultas e podiam proporcionar benefícios ou malefícios. Os fenômenos naturais e os astros, na base da pirâmide, estavam a serviço dos homens e de suas comunidades. Todas essas forças impessoais eram dominadas pelos homens, sobretudo pelos especialistas da magia, que as utilizavam como instrumentos próprios (Altuna, 1985: 59-60).

Os ritos na tradição religiosa banto eram meios estruturados pelos quais esses especialistas atuavam tanto sobre influências hostis quanto sobre influências favoráveis às pessoas e 
comunidades, seja para fins de ataque, seja para fins de defesa. Na cosmovisão banto, a magia era entendida como manipulação da interdependência entre seres viventes e não viventes. 0 princípio é o mesmo, o que muda é a intenção do líder espiritual. Quando utilizada para malefícios, a magia desestruturava a ordem social e profanava a vontade do Ser Supremo, afetando toda a cadeia de interações e com isso trazendo prejuízos para os seres humanos e suas comunidades. A atuação religiosa para fins malevolentes podia trazer resultados desastrosos para toda a comunidade, como aumento da desigualdade social e econômica. Por outro lado, quando usada para trazer benefícios, a magia atuava no sentido de restabelecer e reforçar a harmonia e o equilíbrio perdidos, desencadeando energias compensadoras, capazes de neutralizar e proteger pessoas e comunidades contra forças maléficas (Malandrino, 2010: 99-101; Sweet, 2007: 191-192).

Nessas situações de busca por benefícios, o culto aos ancestrais e antepassados era um meio fundamental de garantir a continuidade ou o fortalecimento da energia vital, assegurando assim a ordenação da vida. É nesse sentido que essas entidades demandavam constante atenção dos vivos para que a cadeia de interação da força vital permanecesse ativa (Munanga, 1996: 62; Éboli, 2010: 29, Malandrino, 2010: 80). As relações dos homens e suas comunidades com seus antepassados eram orientadas pelo princípio de veneração. Os bantos precisavam todo tempo atender aos desejos e prescrições expressos por seus mortos. A interação entre eles era marcada por uma ânsia de comunhão na qual conviviam sentimentos de admiração, medo e respeito profundo. Os antepassados comunicavam-se com seus descendentes por meio de uma possessão maléfica ou benéfica. No primeiro caso, cabia ao especialista da magia promover uma espécie de exorcismo, corrigindo distúrbios na cadeia de interação das forças vitais e procurando um ajuste na relação entre o antepassado e o corpo no qual ele se manifestava. No caso da possessão benéfica, a pessoa que era possuída passava a ser vista como uma privilegiada e podia até transformar-se, pelo transe, em um sacerdote ou médium, assumindo função de oráculo de modo que suas palavras se tornavam palavras do antepassado (Éboli, 2010: 33). A possessão era portanto um meio privilegiado para alcançar a adivinhação tanto das causas que haviam gerado a perda do equilíbrio quanto dos desejos e necessidades dos antepassados. Só assim era possível obter a cura (recuperação da harmonia) em seus diversos sentidos.

Por meio dos rituais os bantos transmitiam sua tradição oral e assim preservavam a sabedoria dos seus ancestrais, que se prolongava nos descendentes. Os cânticos, as palmas, os tambores e as danças confluíam para a manutenção e fortalecimento da cadeia de interações. Por meio desses elementos, os homens e suas comunidades entravam em sintonia com os seres espirituais. Em todas essas práticas religiosas, a palavra possuía um sentido sagrado e sacralizador por ser entendida como veículo de transmissão e expansão da força vital. 
Havia também uma hierarquia nessa concepção, de modo que as palavras de um ancião ou sacerdote tinham mais poder do que as de um ser humano que não ocupava tais funções na sociedade. As palavras, de um modo geral, tinham um poder criador ou destruidor, podendo trazer benefícios ou maldições, gerar ordem ou caos. Portanto, nos rituais, elas deviam ser pronunciadas com prudência e em ritmos adequados, em cadências só dominadas pelos especialistas da magia (Giroto, 1999: 84-87).

Os homens apresentavam oferendas aos antepassados como forma de influenciá-los, obter favores e solucionar problemas. Por isso ofereciam aos seus mortos vegetais, fumo, bebidas alcoólicas, entre outros, conforme o costume específico de um grupo filiado à tradição banto. Em alguns casos também eram ofertados sacrifícios de animais como forma de adensar as relações e interações entre os dois mundos. Tanto as oferendas como os sacrifícios transmitiam força vital e recuperavam o equilíbrio e a harmonia perdidos, contribuindo assim para a retomada da ordem (Malandrino, 2010: 93).

Os povos bantos acreditavam que as almas dos mortos tinham que atravessar a grande massa de água para se encontrar com seus antepassados, sem contudo abandonar completamente o mundo dos vivos. Isso porque a morte era entendida não como extermínio do ser, mas como diminuição de sua energia vital. Nesse sentido, cabia aos descendentes vivos de um defunto assumir alguns compromissos diante de seus mortos, prestando-lhes oferendas em suas sepulturas, em troca de suas forças vitais (Sweet, 2007: 128-129). Assim, era possível garantir a preservação ou aumento da força vital. Os antepassados permaneciam ligados ao cotidiano de seus familiares vivos, atuando de modo influente sobre seus destinos. Para garantir o cumprimento de regras e padrões morais, eles intervinham em disputas comunitárias, assistiam mulheres na hora do parto, garantiam fartura nas colheitas e ainda protegiam caçadores.

De um modo geral, pode-se dizer que entre os bantos não era corrente a visão dualista que opunha o bem ao mal. 0 ódio, o despeito, a vingança e até mesmo o esquecimento podiam desvirtuar a cadeia de interação das energias gerando uma força vital degenerada, deformada e pervertida, sustentada por espíritos, antepassados, feiticeiros ou mesmo pessoas comuns. Tudo isso podia afetar o equilíbrio entre o mundo dos vivos e o mundo dos mortos (Altuna, 1985: 469). Na tradição centro-africana, o que os cristãos nomeavam como o mal em um sentido absoluto era algo relativo e circunstancial que residia apenas nas intenções dos vivos, não possuindo, portanto, um status sobrenatural (Thornton, 2008: 92).

Após a apresentação da síntese das características centrais da religião dos bantos, é possível compreender o calundu colonial como uma espécie de experiência religiosa que reatualizava os preceitos básicos da tradição centro-africana, mesmo considerando-se certa heterogeneidade e as transformações nesse ritual, como veremos adiante. 


\section{CALUNDUS COLONIAis: REATUALIZAÇÕES DA RELIGIÃO DOS BANTOS NA DIÁSPORA AFRICANA NO BRASIL}

N as últimas décadas, pesquisas acadêmicas revelaram a extraordinária quantidade de escravos traficados da África Central para o Brasil entre os séculos XVI e XIX. Nesse período, $45 \%$ ou cerca de 5 dos 11 milhões de africanos traficados como escravos para as Américas eram centro-africanos. Segundo Robert Slenes, essas pessoas escravizadas descobriram desde o continente africano, em sua jornada do interior dos sertões rumo à Costa Atlântica - e mesmo durante a travessia no navio negreiro -, que tinham muito em comum. Apesar das diferenças étnicas, compartilhavam a mesma cosmovisão banto (Slenes, 2007: 116).

Tais constatações nos levam a pensar na força da tradição banto na configuração da experiência religiosa do Calundu. Esse ritual religioso de origem centro-africana era praticado no Brasil, principalmente na Bahia e em Minas Gerais, durante o período colonial. Embora seja evidente a presença de uma variedade de ritos distintos que recebiam o nome de calundu, muitos tinham em comum o uso de instrumentos de percussão, a invocação de espíritos (muitas vezes de defuntos a quem se faziam oferendas), a possessão, a adivinhação e a busca da cura de doenças (Souza, 1986: 269; Marcussi, 2009: 6).

Nas sessões de calundu, muitas pessoas buscavam a cura de distúrbios mentais, perturbações espirituais ou mesmo doenças físicas como tuberculose, varíola, lepra, entre outras (Silveira, 2009: 18). Por meio da adivinhação, parte inerente ao ritual, também era possível descobrir a localização de objetos perdidos, revelar se um acusado de um crime era culpado ou inocente, quais eram as causas de uma doença, entre tantas outras revelações (Sweet, 2007: 145). Os calundus não eram realizados em templos nem em terreiros específicos para fins religiosos. Seus rituais aconteciam em espaços domésticos das casas e fazendas, atraindo grande número de pessoas de vários segmentos sociais, não se restringindo o público apenas a escravos e afrodescendentes livres (Silveira, 2009:18).

No início dos rituais do calundu, os cânticos, as danças e o toque de instrumentos de percussão precediam ao mesmo tempo que estimulavam o transe do celebrante. Este em geral vestia-se com roupas especiais, portando panos, fitas e penas na cabeça. Geralmente contava com dois ou três assistentes, encarregados de tocar os instrumentos e auxiliá-lo na preparação da invocação, nas oferendas e no preparo das ervas e raízes. A mediunidade e as danças eram em geral restritas ao oficiante do rito, cuja finalidade principal era a adivinhação e a cura (Parés, 2007: 113).

Assim como na tradição religiosa africana banto, a experiência de possessão no calundu colonial permitia ao especialista da magia incorporar as energias de seus antepassados, 
socializando seus saberes e promovendo a cura de diversos males, aliviando assim as dores do cativeiro (Antonacci, 2009: 62). Após saltar e cair ao chão por algum tempo, o possuído permanecia imóvel como se estivesse morto (Nogueira, 2009: 3). Em seguida, o oficiante do rito, movido pelos chamados "ventos de adivinhar", promovia um diagnóstico dos males que afligiam seus clientes. Em geral, descobria-se que a causa da doença ou perturbação estava associada a alguma feitiçaria feita por um inimigo do cliente. Ao entrar em transe embalado pelo som dos atabaques tocados por seus ajudantes, o oficiante geralmente produzia urros e sua voz era alterada, sinalizando a presença incorporada de um antepassado que conversava com seus descendentes, respondendo a perguntas e prestando consultas (Nogueira, 2009: 5; Sweet, 2007: 167). Os sacerdotes, oficiantes do calundu vulgarmente conhecidos como feiticeiros, atuavam como médiuns e invocavam o espírito de um antepassado, que entrava em seu corpo e conversava com as pessoas presentes (Sweet, 2007: 173; Nogueira, 2009: 3).

Em suma, o esquema recorrente era baseado nos seguintes passos: invocação (com 0 auxílio dos cantos e toques de instrumentos executados pelos auxiliares do oficiante), possessão do oficiante (seguida de oferendas de comidas e bebidas ao espírito incorporado), adivinhação (dos males físicos ou espirituais que afligiam os presentes) e cura (prometida por meio da ingestão de preparos de ervas e raízes). Em alguns casos, nem sempre recorrentes, também era usada a unção com sangue de galinha, vaca ou outro animal sacrificado para induzir os espíritos a possuírem o mestre dos calundus (Sweet, 2007: 180-184). Nos casos de calundus em que eram sacrificados animais, o sangue era usado durante a invocação e a carne era utilizada como oferenda aos antepassados.

Os elementos aqui descritos como características gerais do calundu podem ser melhor observados, com pequenas variações, no estudo de alguns casos conhecidos por meio dos processos inquisitoriais. Com base na documentação de Luzia Pinta, é possível reconstituir em parte seu calundu. Após muitos anos de cativeiro em Sabará, Minas Gerais, Luzia conseguiu sua alforria e chegou a comprar três escravos que atuavam como seus ajudantes no calundu. Ela presidia os rituais, celebrados em sua própria casa ou na residência de seus assistidos. No início da cerimônia, em uma espécie de altar, Luzia permanecia assentada em uma cadeira. ${ }^{3}$ Ao som dos tambores e atabaques tocados por seus escravos como forma de invocação dos espíritos, Luzia marcava com os pés e os braços o compasso da música até "ficar fora de seu juízo, falando coisa que ninguém entendia". Em seguida ela começava a pular, tremer e gritar palavras e frases desconhecidas, entrando em uma espécie de transe. Esse era, sem dúvida, 0 momento da possessão que, segundo testemunhas, deixava Luzia "horrorosa e enfurecida". Ao ser interrogada pela inquisição, Luzia Pinta confessou que o calundu "se pega de umas pessoas a outras e que a ela Iho teria comunicado uma tia sua, chamada Maria" já falecida. ${ }^{4}$ 
Assim como em outros casos de oficiantes do calundu, a comunicação se dava dentro da parentela. Em consonância com a religião dos bantos, o oficiante do calundu, ao entrar em plena sintonia e comunhão com seus antepassados, podia assim promover a restauração do equilíbrio, orientando aqueles que estivessem sofrendo perturbações ou doenças.

Após constatar a possessão, os auxiliares de Luzia soltavam uma cinta antes amarrada em sua barriga e colocavam alguns penachos coloridos em sua orelha, de onde ela dizia receber "ventos de adivinhar". Nesse momento iniciava-se a adivinhação, quando os participantes eram convidados a se ajoelhar e passavam a ser cheirados e assoprados, sendo tais atos considerados uma forma de diagnóstico das doenças e queixas. Em seu depoimento, Luzia afirmou que, "ficando fora de si, entrava a dizer os remédios que se há de aplicar, e a forma na qual se hão de fazer". Aqueles identificados como pessoas enfeitiçadas recebiam pó ou ervas ora sobre suas cabeças ora em suas bocas, sempre ao som dos gritos da oficiante, que muitas vezes precisava ser acalmada pelos seus auxiliares. ${ }^{5}$

Durante o ritual, realizado geralmente à noite e chegando a durar em torno de duas horas, o oficiante em estado de transe preparava misturas de raízes e ervas e as oferecia ao cliente, que chegava a vomitar ou defecar, expelindo assim os espíritos malignos e objetos mágicos que o atormentavam. As práticas da oferenda e do sacrifício não aparecem de modo explícito no processo inquisitorial de Luzia Pinta, diferentemente de outros calundus. Isso não significa que esse elemento não estivesse presente em seu ritual. Há registros de que durante a possessão ela ingeria e oferecia aos circundantes "certa bebida de vinhos" . ${ }^{6}$ Esse talvez seja um indício significativo da oferenda de bebidas aos espíritos.

Em outros calundus, o oficiante do ritual ingeria oferendas de comidas e bebidas durante a possessão para agradar aos antepassados. Entre as oferendas mais comuns e recorrentes, figurava o aluá, um preparo alcoólico feito da fermentação de ananás, farinha de milho e de arroz. Essas ofertas serviam também para apaziguar os espíritos mais zangados ou envergonhados, estimulando sua cooperação (Sweet, 2007: 177-178). É possível que essa tenha sido a bebida presente no calundu de Luzia Pinta. Em todo caso, em seu ritual é possível encontrar a invocação, a possessão, a adivinhação e a cura, elementos centrais e recorrentes em muitos outros calundus.

A presença da oferenda e do sacrifício pode ser melhor observada no calundu da escrava Branca, na Bahia, que no início do século XVIII entrava em transe e oferecia cura aos que assistiam a seus rituais. Sob o toque de instrumentos musicais, como canzás e tabaques, ela frequentemente dançava e cantava na "língua de Angola" invocando seus parentes mortos. Em 1701, durante um ritual de calundu realizado na propriedade de seu senhor Pedro de Siqueira, após um grande salto ela caiu inconsciente no chão. Em seguida, foi assistida por 
duas auxiliares que a cobriram com uma "pele de gato pintada", um pano vermelho e outro branco, além de colocar um capuz e um punhal em suas mãos. Após algum tempo, a escrava se levantou e começou a falar com uma voz diferente, reconhecida pelos presentes como a voz do seu filho, falecido. Entre os presentes ao ritual estava Felícia Pires, uma mulher branca de 41 anos que ofereceu uma vaca em busca da cura de sua cegueira. As assistentes prepararam uma mesa com comidas e bebidas para saciar a fome e agradar o espírito incorporado em Branca. Após receber essas oferendas, entre elas o aluá, Branca preparou (ainda em estado de transe) uma mistura de raízes e ervas destinadas à cura da cegueira de Felícia. ${ }^{7}$

0 calundu de Branca orientava-se pelos mesmos princípios básicos dos rituais centro-africanos bantos. Ela usava riscos de um barro branco chamado mpemba no corpo ou na face para facilitar seu acesso ao mundo dos mortos, onde habitavam os antepassados que deveriam possuí-la. Acreditava-se que os mortos deixavam seus corpos e migravam para o mpemba, mundo subterrâneo do barro branco. Assim, essa substância passou a ser considerada o símbolo dos mortos benevolentes, e era por isso muito utilizada como elemento de proteção entre os centro-africanos (Sweet, 2007: 177-178).

Em alguns casos, como no calundu de Ângela Vieira, a oferenda de bebidas e comidas aos antepassados ou mesmo o sacrifício de animais também aparecem de modo explícito. Ângela, uma escrava liberta de origem angolana, era a oficiante do ritual. Em 1712, na Bahia, ela ungiu-se com o sangue de um bezerro, sacrificado com a ajuda de seus auxiliares. 0 animal havia sido doado por um comerciante chamado Dionízio Soares e por sua companheira, uma parda chamada Josefa. Ambos buscavam no calundu a adivinhação dos motivos de suas doenças, bem como as raízes e ervas adequadas para sua cura. ${ }^{8}$

\section{CONSIDERAÇÕES FINAIS}

$\mathrm{O}$ que em geral caracterizava a dinâmica das experiências religiosas centro-africanas era sua capacidade de renovação, abrindo-se a novos movimentos religiosos. Mesmo em território africano, era comum que, sob a liderança de líderes carismáticos, ocorresse a reinterpretação de símbolos, objetos, rituais e mitos estrangeiros. Não se tratava, no entanto, do abandono dos aspectos centrais da religião dos bantos. As novas experiências religiosas eram conduzidas de modo a incorporar elementos estrangeiros com o objetivo de prevenção do infortúnio e maximização da boa sorte (Craemer; Vansina; Fox, 1976:461). Em outras palavras, mantinha-se a estrutura da cosmologia banto incorporando-se novos elementos.

Essa dinâmica parece ser a chave da compreensão do calundu no Brasil. Em linhas gerais, é possível perceber nitidamente a sobrevivência dos princípios fundamentais da religião 
dos povos bantos, como a relação com os antepassados, a possessão por espíritos, a busca pela restauração do equilíbrio e da energia vital e, em alguns casos, as oferendas e sacrifícios. Os elementos aqui apresentados desenham o esboço de alguns aspectos centrais do repertório simbólico da cosmovisão banto que serviam de matriz e fundamento para a configuração do calundu. Somente por meio do conhecimento das tradições religiosas bantos é possível situar e entender os calundus no Brasil colonial.

Acima de tudo, os calundus - vulgarmente classificados pela perspectiva eurocêntrica como feitiçaria - tinham o objetivo maior de restaurar o equilíbrio e a harmonia de pessoas e comunidades, corrigindo distúrbios na cadeia de interações de energias vitais. Oficiantes como Luzia Pinta, Branca ou Ângela, assim como os líderes espirituais dos povos bantos, atuavam por meio da possessão, como um adivinho/curandeiro revestido de poderes religiosos que o capacitavam a incorporar os espíritos, agradá-los ou expulsá-los conforme o caso (Sweet, 2007: 191-192).

As reflexões apresentadas neste artigo não nos levam a entender os significados centro-africanos como estáticos ou congelados no tempo. Ao contrário, a cosmovisão banto oferecia um repertório de sentidos e orientações cognitivas que eram acionados de modo diferenciado conforme as circunstâncias e a diversidade de experiências religiosas desfrutadas pelos bantos e seus descendentes no Brasil. Também não se deve negar certa heterogeneidade ou mesmo transformações no ritual reveladas, por exemplo, pela ausência de oferendas ou de sacrifício de animais em alguns casos e pela incorporação de elementos da tradição religiosa católica. 0 desafio maior é entender a dinâmica que orientava as permanências e também as transformações por meio de modos próprios de acesso e seleção aos repertórios simbólicos católicos e africanos.

Assim, a adesão ao cristianismo por parte dos africanos bantos no Brasil não implicava o abandono ou a diluição completa e rápida das tradições religiosas de sua terra mãe. Os povos bantos e seus descendentes, praticantes do calundu colonial, conseguiram acomodar aspectos da cosmologia cristã em seus rituais. Os olhares externos, por desconhecerem tal dinâmica, classificaram o calundu, de modo apressado, como prática sincrética, entendida como simples mistura de várias tradições religiosas.

Em consonância com Alexandre Marcussi, acredito que a compreensão do calundu colonial não deve passar por uma escolha entre dois polos excludentes que o situam na chave da permanência (recriação de africanismos que se mantêm praticamente intactos) ou da mudança (processo de diluição completa de heranças culturais e religiosas por meio do sincretismo). Acredito, no entanto, que a compreensão daquela dupla interpretabilidade passe necessariamente pelo conhecimento da tradição religiosa dos povos bantos, sem o qual não se pode nem mesmo conhecer as transformações no ritual. 
0 calundu, portanto, deve a meu ver ser interpretado como uma reatualização da tradição religiosa dos povos bantos, em um processo lento que abrigava tanto a permanência de princípios gerais quanto a incorporação de alterações dentro de uma estrutura básica recorrente. Acredito assim que o conhecimento da religião dos bantos, a partir de suas dinâmicas de renovação e atualização, traz elementos significativos para o empreendimento de futuras "novas visitas", não só ao calundu de Luzia, mas também ao de Ângela, Branca e tantos outros personagens possuídos pelos "ventos de advinhar" soprados no Brasil pela diáspora africana banto.

\section{NotAS}

1 Arquivo Nacional da Torre do Tombo. Inquisição de Lisboa. Processo 252, maço 26. Disponível em: http:// digitarq.dgarq.gov.pt/details?id=2300124. Acesso em 28 de março de 2015.

2 Em algumas comunidades bantos encontra-se também a crença nos heróis antigos ou civilizadores, categoria de introdução mais recente, encarregados de colaborar com a divindade e introduzir técnicas e inovações (Altuna, 1985: 58-59; Giroto, 1999: 95-96).

3 Arquivo Nacional da Torre do Tombo. Inquisição de Lisboa. Processo 252, fl. 26. Site e data de acesso indicados na nota 1.

4 Arquivo Nacional da Torre do Tombo. Inquisição de Lisboa. Processo 252, fl. 23. Site e data de acesso indicados na nota 1.

5 Arquivo Nacional da Torre do Tombo. Inquisição de Lisboa. Processo 252, fl. 26. Site e data de acesso indicados na nota 1.

6 Idem.

7 Arquivo Nacional da Torre do Tombo. Inquisição de Lisboa. Cadernos do Promotor, n. 81, livro 274, fls 240248. Site indicado na nota 1, acesso em 31 de março de 2015.

8 Arquivo Nacional da Torre do Tombo. Inquisição de Lisboa. Cadernos do Promotor, n. 80, livro 273, fl. 29. Site indicado na nota 1, acesso em 2 de abril de 2015.

\section{REFERÊNCIAS BIBLIOGRÁFICAS}

ALCANTARA, Renato de. A tradição da narrativa no Jongo. Dissertação (Mestrado em Ciência da Literatura), UFRJ, 2008.

ALTUNA, Raul Ruiz de Asús. A cultura tradicional banto. Luanda: Secretariado Arquidiocesano de Pastoral, 1985.

ANTONACCI, Maria Antonieta. África/Brasil: corpos, tempos e histórias silenciadas. Tempo e Argumento. Florianópolis, v. 1, n. 1, p. 46-67, jan.- jun. 2009. 
CRAEMER, Willy de; VANSINA, Jan; FOX, Renée C. Religious movements in Central Africa: a theoretical study. Comparative Studies in Society and History, Cambridge: Cambridge University Press, v. 18, n. 4, p. 458-475, oct. 1976.

DINES, Alberto. Vínculos de fogo: Antônio José da Silva, o Judeu e outras histórias da Inquisição em Portugal e no Brasil. São Paulo: Companhia das Letras, 1992.

ÉBOLI, Luciana Morteo. Memória e tradição nos dramas de São Tomé e Príncipe e Angola: os teatros de Fernando de Macedo e José Mena Abrantes. Tese (Doutorado em Teoria da Literatura), PUC-RS, 2010.

GIROTO, Ismael. O universo mágico-religioso negro-africano e afro-brasileiro: bantu e nagô. Tese (Doutorado em Antropologia), USP, 1999.

LOPES, Nei. Bantos, malês e identidade negra. Belo Horizonte: Autêntica, 2008.

MACGAFFEY, Wyatt. Religion and society in Central Africa: the Bakongo of Lower Zaire. Chicago/London: The University of Chicago Press, 1986.

MARCUSSI, Alexandre. Estratégias de mediação simbólica em um calundu colonial. Revista de História da USP, São Paulo, v. 155, p. 97-124, 2006.

Iniciações rituais nas Minas Gerais do século XVIII: os calundus de Luzia Pinta. In: Anais do /I Encontro Nacional do GT História das Religiões e das Religiosidades, Revista Brasileira de História das Religiões, Maringá, v. 1, n.3, 2009.

MALANDRINO, Brígida Carla. "Há sempre confiança de que se estará ligado a alguém": dimensões utópicas das expressões da religiosidade bantú no Brasil. Tese (Doutorado em Ciências da Religião), PUC São Paulo, 2010.

MOTT, Luiz. 0 calundu-Angola de Luzia Pinta: Sabará, 1739. Revista do Instituto de Arte e Cultura, Ouro Preto, n. 1, p. 73-82, dez. 1994.

MUNANGA, Kabengele. Origem e histórico do quilombo na África. Revista da USP, São Paulo, n. 28, p. 56-63, dez. 1995-fev.1996.

NOGUEIRA, André. Os calundus e as Minas Gerais do século XVIII. Anais do XXV Simpósio Nacional de História. Fortaleza: ANPUH, 2009.

PARÉS, Luis Nicolau. A formação do candomblé: história e ritual da nação jeje na Bahia. 2 ed. rev. Campinas: Editora da Unicamp, 2007.

SILVA, Norma Maria Jacinto. Os fios da memória e da história em "De rios velhos e guerrilheiros": o livro dos rios. Dissertação (Mestrado em Letras Vernáculas), UFRJ, Rio de Janeiro, 2009.

SILVEIRA, Renato. Do calundu ao candomblé: os rituais de fé africanos ganham seu primeiro tempo no início do século XIX. In: FIGUEIREDO, Luciano (org.) Raízes africanas. Rio de Janeiro: SABIN, 2009.

SLENES, Robert. "Eu venho de muito longe, eu venho cavando: jongueiros cumba na senzala centro-africana". In: LARA, Silvia Hunold \& PACHECO, Gustavo (orgs.). Memória do jongo: as gravações históricas de Stanley Stein (Vassouras, 1949). Rio de Janeiro: Folha Seca/ Campinas: CECULT, 2007.

SOUZA, Laura de Mello. O diabo e a Terra de Santa Cruz: feitiçaria e religiosidade popular no Brasil colonial. São Paulo: Companhia das Letras, 1986. 
Revisitando o calundu. In: GORENSTEIN, Lina e CARNEIRO, Maria L. Tucci (org.). Ensaios sobre a intolerância: Inquisição, Marranismo e Anti-Semitismo. São Paulo: Humanitas, 2002, p. 293-317.

SWEET, James H. Recriar África: cultura, parentesco e religião no mundo afro-português (1441-1770). Lisboa: Edições 70, 2007.

THORNTON, John. Religião e vida cerimonial no Congo e áreas umbundo, de 1500 a 1700. In: HEYWOOD, Linda (org.). Diáspora negra no Brasil. São Paulo: Contexto, 2008.

TEMPELS, Placide. La philosofie Bantue. Paris: Présence Africaine, 1961.

VANSINA, J. Les anciens royaumes de La Savane. Institut de Recherches Economiques et Sociales, Université Lovanium, Leopoldville, 1965b. 